\title{
A STUDY ON HISTOMORPHOLOGICAL SPECTRUM OF CHILDHOOD MALIGNANT TUMOUR: EVALUATION OF 60 CASES AT DIFFERENT CENTER IN DHAKA CITY.
}

\author{
Karim $\mathrm{MI}^{1}$, Ali SM${ }^{2}$, Akhter $\mathrm{S}^{3}$, Islam $\mathrm{SMJ}^{4}$, Karim $\mathrm{MM}^{5}$, Alam $\mathrm{MR}^{6}$
}

\begin{abstract}
Introduction: About $2 \%$ of all malignant tumours occur in infancy and childhood. Malignancy is the second common cause of childhood death in developed world, accounting for $10-12.3 \%$ of all childhood deaths. Eighty eight percent of world's children live in developing countries, where access to adequate care is limited. Incidence of childhood cancer is increasing in this region gradually.
\end{abstract}

Objectives: The objective of this study was to find out the histomorphological pattern of childhood cancers in our country and assess the trends of malignancies in different age group.

Methods: This prospective study was carried out from January 2008 to January 2012. During this period data was analyzed for the malignancies occurring in the age group 0-14 years. Data was categorized according to incidence of paediatric malignancies in different age groups, sex and types of tumours. All the children below 15 years with confirmed diagnosis of cancer by means of histopathological examinations were included in this study.

Results: Total 3120 patients were diagnosed as having malignancies at Armed Forces Institute of Pathology (AFIP), Delta Hospital Ltd \& Bangabandhu Sheikh Mujib Medical University (BSMMU) Dhaka, out of which 60 cases were paediatric malignant tumours. Overall incidence of paediatric tumour was $1.92 \%$. Out of which 26 cases $(43.33 \%)$ were female and $34(56.66 \%)$ cases male. The male - female ratio was 1.3:1. Males were more affected than females. The peak incidence of paediatric tumors $(37 \%)$ was found in children between the age group 10 to 14 yrs. The pattern of childhood tumours shows wide variation among the age groups. In this study, at 0-4 yrs age group small round cell tumours (Neuroblastoma, Retinoblastoma), 5-9 yrs germ cell tumour, 10-14 yrs bone tumour (Ewing sarcoma, Osteosarcoma) were the commonest tumour.

Conclusion: We conclude that there are certain notable differences between tumours of our study and those reported from other parts of the world. In our study small round cell tumor is most frequent childhood tumour.

Key-Words: Childhood malignancies, Small round cell tumour, Incidence, Histomorphology

1. Lt Col Md Iqbal Karim, MBBS, MCPS, DCP, FCPS (Histopathology), Asst Prof of Pathology, AFMC, Dhaka Cantonment. 2. Prof Syed Mukarram Ali, MBBS, DCP, FRCP, FCPS. Prof of Pathology, BCPS. 3. Col Selina Akhter, MBBS, MCPS, FCPS (Histopathology),Classified Specialist in Pathology, AFIP, Dhaka Cantt. 4. Lt Col Sk Md Jaynul Islam, MBBS, MCPS, DCP, FCPS (Histopathology), Classified Specialist in Pathology, BNS Patenga Hospital. 5. Lt Col Md Mostafil Karim, MBBS, MCPS, DCP, FCPS (Haematology), Asst Prof of Blood transfusion, AFMC, Dhaka Cantt. 6. Maj Md Rabiul Alam, MBBS, D-Av Med, Graded Spl in Aerospace Medicine, BAF Base Banga Bandhu, Kurmitola. 


\section{Introduction}

Childhood malignant tumour constitutes one of the most important groups of tumors. Eighty eight percent of world's children live in developing countries, where access to adequate care is limited $^{1}$. Incidence of paediatric tumours is on rise all over the world. Malignant neoplasms are rare in children, yet it is an important cause of childhood mortality in many of the economically developed nations of the world. Malignancy is the second common cause of childhood death in developed world, accounting for $10-12.3 \%$ of all childhood deaths $^{2}$. It is the second major cause of childhood mortality after accidents in $\mathrm{USA}^{3}$. In developing countries like Bangladesh, India, Pakistan childhood mortality is still higher due to malnutrition and infections but paediatric tumours are also rising in number. Because of major advances in diagnosis, multi-modality therapy, development of rational use of combination chemotherapy and improved supportive care, the cure rate in childhood cancer has increased tremendously and over $60 \%$ of all childhood cancers are now curable ${ }^{4}$. Good quality population level statistics on the occurrence of cancer at young age have been more difficult to obtain than in adults. Serious under reporting even in western countries has been documented ${ }^{5}$. Appropriate management of paediatric tumours requires complete epidemiological data of paediatric tumours in different geographical areas. In our neighboring countries like India, Pakistan have many well documented studies of paediatric tumour, on the other hand Bangladesh have very few studies regarding this age specific paediatric malignancies.

\section{Materials and Methods}

We used four years prospective studies in January 2008 to January 2012 at Armed Forces Institute of Pathology, Dhaka Cantonment, Bangabandhu Sheikh Mujib Medical University and Delta Hospital Ltd, Dhaka. All children with paediatric tumour, aged $0-14$ years diagnosed by means of histological and cytological examination during that period were included in this study. Cytologically diagnosed cases were confirmed by histopathological examination. Patients were from Armed forces personnel, their families \& civil patients operated in different hospital in Dhaka city. The patients were stratified by gender, 5 years age groups $(0-4$ years +$), 5$ to less than 10 years $(5-9$ years +$), 10$ to less than 15 years $(10-14$ years +$)$ according to the International Classification of Childhood Cancers (ICCC) diagnostic groups(IARC,1996) ${ }^{6}$. The paediatric malignant tumours were analysed according to age, sex and histopathological diagnosis. All tumours were diagnosed on routine haematoxyline and eosin staining. As the diagnosis predominantly based on histopathological examination, so we excluded haematological malignancies like leukaemia from our study.

\section{Results}

In our study for sorting the childhood malignancies, we had to examine 3120 patients who were diagnosed as having malignancies, out of which 60 cases were of paediatric age group. The paediatric malignant tumour comprises $1.92 \%$ of all malignancies.

This study found total 60 paediatric malignancies cases. Out of which 26 cases $(43.33 \%)$ were female and $34(56.66 \%)$ cases male. The male female ratio was $1.3: 1$. So it was observed that male affected more than female. The age ranges of patients were from 0 to 14 years. The patients were divided into three age groups. 1 st group is 0 to 4 years of age, 2 nd group is 5 to 9 years of age and 3rd group is 10 to 14 years of age. Most of the childhood malignant tumour was found in the 3 rd group $22(37 \%)$ cases, then 1 st group 21 $(35 \%)$ cases and least number of tumour found in the 2nd age group $17(28 \%)$ cases. The sex distribution, age groups, histopathogical types and incidence in percentage are shown in the Table-I. 
Table- I : Childhood malignant tumours according to age and sex $(n=60)$

\begin{tabular}{|c|c|c|c|c|c|c|}
\hline Type of tumour & $\mathbf{M}$ & $\mathbf{F}$ & $0-04$ yrs & $05-09$ yrs & $10-14$ yrs & Percentage (\%) \\
\hline Non Hodgkin Lymphoma & 8 & 1 & 2 & 2 & 5 & $15 \%$ \\
\hline Hodgkin Lymphoma & 6 & 2 & 2 & 5 & 1 & $13.33 \%$ \\
\hline Germ cell tumour & 1 & 8 & 2 & 6 & 1 & $15 \%$ \\
\hline Neuroblastoma & 4 & 2 & 3 & 1 & 2 & $10 \%$ \\
\hline Retinoblastoma & 2 & 3 & 3 & 2 & - & $8.33 \%$ \\
\hline Wilms tumour & 3 & 2 & 3 & - & 2 & $8.33 \%$ \\
\hline Ewings sarcoma & 4 & - & - & 1 & 3 & $6.67 \%$ \\
\hline Rhabdomyosarcoma & - & 2 & 2 & - & - & $3.33 \%$ \\
\hline Papillary ca of thyroid & 1 & 2 & - & - & 3 & $5 \%$ \\
\hline Osteosarcoma & 2 & 1 & - & - & 3 & $5 \%$ \\
\hline Brain tumour & 1 & 1 & 2 & - & - & $3.33 \%$ \\
\hline Metastatic carcinoma & 1 & - & - & - & 1 & $1.67 \%$ \\
\hline Squamous cell ca & - & 1 & - & - & 1 & $1.67 \%$ \\
\hline Mucoepidermoid carcinoma & 1 & - & - & - & 1 & $1.67 \%$ \\
\hline \multirow[t]{2}{*}{ Adenocarcinoma } & - & 1 & - & - & 1 & $1.67 \%$ \\
\hline & 34 & 26 & 19 & 17 & 24 & $100 \%$ \\
\hline
\end{tabular}

Among 60 malignant cases, small round cell malignant tumours were 33 cases (55\%). Rest of the tumours were Hodgkin Lymphoma 08 cases (13.33\%), malignant germ cell tumour 09 cases (15\%), Papillary carcinoma of thyroid 03 cases (5\%), Osteosarcoma 03 cases (5\%) and others (Squamous cell carcinoma, Mucoepidermoid carcinoma, Adenocarcinoma, Ependymoma) 04 cases (6.67\%). The pattern of malignant tumour is shown in the Table-II. 
Table-II: Histomorphological pattern of childhood malignant tumour $(\mathrm{n}=60)$

\begin{tabular}{|l|l|}
\hline Tumour & Frequency $(\mathbf{n = 6 0})$ \\
\hline $\begin{array}{l}\text { Small round } \\
\text { cell tumour }\end{array}$ & $33(55 \%)$ \\
\hline $\begin{array}{l}\text { Hodgkin's } \\
\text { lymphoma }\end{array}$ & $08(13.33 \%)$ \\
\hline $\begin{array}{l}\text { Malignant germ } \\
\text { cell tumour }\end{array}$ & $09(15.00 \%)$ \\
\hline $\begin{array}{l}\text { Papillary carcinoma } \\
\text { of thyroid }\end{array}$ & $03(5.00 \%)$ \\
\hline Osteosarcoma & $03(5.00 \%)$ \\
\hline Others & $04(6.67 \%)$ \\
\hline
\end{tabular}

Most of the malignant tumour was small round cell tumours $(55 \%)$. These include Neuroblastoma, Retinoblastoma, Nephroblastoma, Ewing's sarcoma, Lymphoblastic lymphoma, Rhabdomyosarcoma and Medulloblastoma. Among the small round cell tumours, lymphoblastic lymphoma was found the most common tumours followed by Neuroblastoma, Retinoblastoma and Nephroblastoma. The pattern of small round cell tumour is found shown in Table-III. \& photographs show microscopic view of Non-Hodgkin lymphoma (Fig-1) \& Retinoblastoma (Fig-2).

Table-III: Distribution of small round cell tumour $(\mathrm{n}=33)$

\begin{tabular}{|l|l|}
\hline Small round cell tumour & Frequency $(\mathbf{n}=33)$ \\
\hline Non Hodgkin lymphoma & 9 \\
\hline Neuroblastoma & 6 \\
\hline Retinoblastoma & 5 \\
\hline Nephroblastoma & 5 \\
\hline Ewings sarcoma & 4 \\
\hline Rhabdomyosarcoma & 2 \\
\hline Medulloblastoma & 2 \\
\hline
\end{tabular}

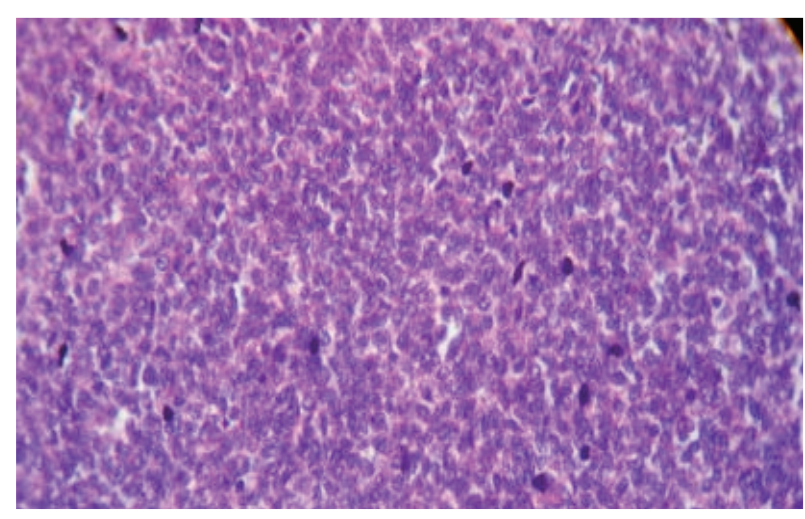

Fig-1 : Non Hodgkin lymphoma

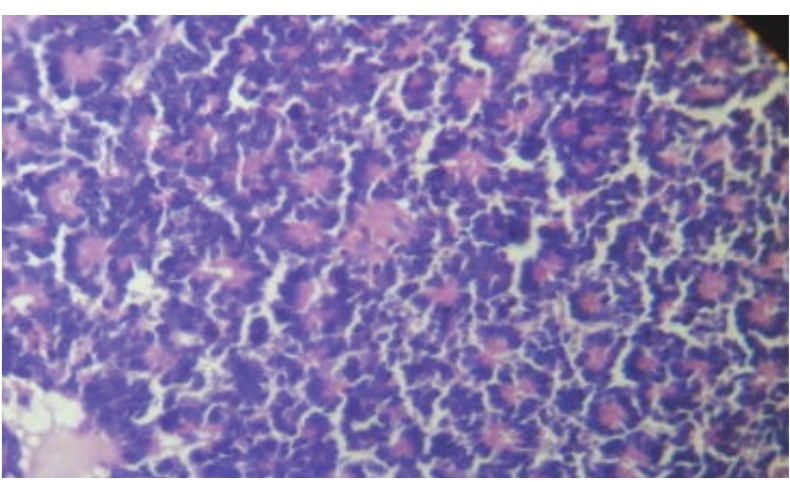

Fig-2 : Retinoblastoma

Germ cell tumours include immature teratoma, yolk sac tumour, embryonal carcinoma and dysgerminoma. The number of immature teratoma is the largest number of germ cell tumour in our study. The pattern of germ cell tumour is shown in the following Table-IV.

Table-IV: Distribution of childhood germ cell tumour $(\mathrm{n}=9)$

\begin{tabular}{|l|l|}
\hline Germ cell tumour & Frequency $(\mathbf{n = 9})$ \\
\hline Immature teratoma & 4 \\
\hline Yolk sac tumour & 3 \\
\hline Embryonal carcinoma & 1 \\
\hline Dysgerminoma & 1 \\
\hline
\end{tabular}




\section{Discussion}

In our study paediatric tumours constituted $1.92 \%$ of all malignancies. It is lower than other studies (3.4\%) in Rathi et $\mathrm{al}^{2}$ and (3.3\%) in Yeole et $\mathrm{al}^{7}$ respectively. Incidence of cancer in India is $1.6-4.8 \%$ and $2 \%$ according to Arora et $\mathrm{al}^{8}$ and Jingnasa $\mathrm{N}$ et $\mathrm{al}^{9}$ respectively which is almost correlates to our study. But our incidence is higher than in England $(0.6 \%)$ and USA $(0.9 \%)^{10}$. Children from a larger part of the population in a developing country where the life expectancy is lower than in the developed countries. The international comparison of cancer frequency and incidence are potentially biased by variability in diagnosis, classification and differential access to medical care and incomplete registration.

In our study the incidence of malignancies is higher in male than female which is almost comparable with both Yeole et $\mathrm{al}^{7}$ and Joshi $\mathrm{V}$ et al10 studies. The ratio is slightly higher than Gurney et al study ${ }^{11}$, which was conducted in USA. Male predominance is a salient feature of the childhood tumours. Sex ratio varies with site. The male excess is particularly seen in neoplasms of lymphoid origin e.g. Non-Hodgkin Lymphoma, Hodgkin Lymphoma, Neuroblastoma \& Ewings sarcoma which represent over half of all tumours. Environmental factors like exposure to carcinogens at work or smoking habits may be contributing to excess of cancers in adult male but such explanation cannot account for the excess of cases seen in male children.

Genetic difference in immune function may be responsible for the increased incidence of lymphoid tumours in male. Male preponderance in our country could be also as a result of our cultural factors wherein boys get more attention and are brought to hospital more often for management. In our study the female excess seen in germ cell tumours may be due to earlier development of ovarian tumours than testicular tumours.

In present study the incidence is more $(40 \%)$ in 10-14 years of age group and next incidence is $0-4$ yrs of age group. This finding well correlates with the previous study by yeole et $\mathrm{al}^{7} \&$ Jabben et $\mathrm{al}^{12}$ which was $39.3 \%$.

In present study, Non Hodgkin lymphoma (15\%) is the most common malignancy in male at the age of $10-14$ yrs. Hodgkin Lymphomas are the 2nd most common malignancy $(13.33 \%)$ which are more prevalence in male at the age of 6-9 yrs. We observed that Non Hodgkin lymphoma was more common than Hodgkin lymphoma which correlates with other study USA and Italy ${ }^{13}$. But it differs to other studies from Pakistan where Hodgkin Lymphoma is more common than Non Hodgkin lymphoma.

Among the malignant tumours, small round cell tumours are the highest number $(55 \%)$ which corresponds to all cases of review literature ${ }^{14}$. Kelly and Joshi et $\mathrm{al}^{15}$ stated that neuroblastic tumours are $7 \%$ to $10 \%$ of all paediatric malignant tumour. Current study shows both neuroblastoma and retinoblastoma are common small round cell tumour $(10 \%)$ at the age of $0-4$ yrs. It correlates with Kelly and Joshi et all study. It indicates that the possible existence of a genetic trait in population of Bangladesh \& India with some regional variety. Paediatric brain tumour are more common in USA and Italy but is the least common tumour in our series because of limitation of brain tumour surgery facilities and late diagnosis.

\section{Conclusion}

We conclude that there are certain notable differences between tumours of our study and those reported from other parts of the world. In our study small round cell tumour is most frequent childhood tumour. Paediatric tumours are a special entity with different genetic, environmental factors playing a role in their etiology. The growth potential and response to treatment is also different from those of adult tumours. Children in developing nations are increasingly affected by malignancy in addition to rampant malnutrition and infection. As many of common childhood malignancies are curable, there needs to have a dedicated paediatric cancer registry for assessing the magnitude of problem in our 
country as paediatric tumours show wide variation across centers. In our study, as malignant small round cell tumours are more prevalent in our territory but it is almost curable, provided timely correct diagnosis and proper treatment. Molecular methods may play a vital role in accurate diagnosis of tumour.

\section{References}

1. Chandra A, Sagar TG, Swaminathan R et al. childhood cancer epidemiology among Asian population in Indian subcontinent. Indian $\mathrm{J}$ Cancer.2004; 56:231-4.

2. Rathi A.K, Kumar A, Ashu A et al. Epidemiology of paediatric tumours at a tertiary care centre; Indian J Med Paediatr Oncol. 2007; 28(2): 33-5.

3. Kusumakumary P, Rojomon J, Jothirmayi R et al. Profile of paediatric malignancies: A ten year study. Indian Paediatrics 2000; 37: 1234-8.

4. Advani S.H. Chemotherapy of childhood tumors. Ind. J Med and Ped. Oncol. 1995; 16: 142-3.

5. Young J.L, Ries L. G, Silverberg E, Horm J. W., Miller R. W. Cancer incidence, survival and mortality for children younger than age 15 years. Cancer 1986; 58:598-602.

6. Steliarova FE,Stiller C,Locour B et al. International classification of childhood cancer.3rd edition.Cancer 2005;103:1457-67.
7. Yeole B.B, Advani S.H, Sunny L. Epidemiological features of childhood cancers in greater Mumbai. Ind. Pediatrics. 2001; 38: 1270-7.

8. Arora R.S, Eden TOB, Kapoor G. Epidemiology of childhood cancer in India. Indian J. of Cancer. 2009; 46(4): 264-73.

9. Jignasa NB. Profile of paediatric malignancy National Journal of Community Medicine.2011; Volume 2 :Issue1.

10. Joshi V, Kumar A. Pediatric Hemato-oncology in India. Epidemiologic Differences. M.B. Agrawal. Hematology Today, 2004.

11. Gurney J.G, Severson R, Devis S, Robinson L.L.Incidence of cancer in children in United States. Cancer 1995; 75(8): 2186-95.

12. Jabeen S, Haque M, Islam M.J, Talukder M.H Profile of pediatric malignancies: A five year study. J Dhaka Med Coll. 2010; 19(1): 33-8.

13. Sandlund JT, Downing JR. Non Hodgkin's Lymphoma in Childhood. The New England Journal of Medicine 1996; 5:1238.

14. Susan L. Cohn: Diagnosis and Classification of the Small Round-Cell Tumors of Childhood. American Journal of Pathology.1999; 155:11-5.

15. Kelly DR, Joshi VV: Neuroblastoma and related tumors, Paediatric Neoplasia Morphology and Biology. Lippincott-Raven, 1996 pp 105-10. 